\title{
УКРАЇНСЬКІ ТОПОНІМИ В ЛІНГВОКРАЇНОЗНАВЧОМУ СЛОВНИКУ ДЛЯ СТУДЕНТІВ-ІНОЗЕМЦІВ
}

\author{
ОКСАНА САМУСЕНКО \\ Київський національний університет імені Тараса Шевченка, Київ - Україна \\ UKRAIŃSKIE TOPONIMY \\ W SŁOWNIKU LINGWISTYCZNO-KRAJOZNAWCZYM \\ DLA STUDENTÓW OBCOKRAJOWCÓW
}

\author{
OKSANA SAMUSENKO
}

Kijowski Uniwersytet Narodowy im. Tarasa Szewczenki, Kijów — Ukraina

STRESZCZENIE. Artykuł poświęcony jest tworzeniu lingwistyczno-krajoznawczego wizerunku Ukrainy w procesie nauczania ukraińskiego jako języka obcego. Szczególną uwagę zwrócono na analizę narodowo-kulturowej semantyki ukraińskich toponimów, kształcenia w tym zakresie cudzoziemców oraz specyfikę przedstawiania materiału w słowniku lingwistyczno-krajoznawczym.

\author{
UKRAINIAN TOPONYMS \\ IN THE CULTURE-THROUGH-LANGUAGE \\ DICTIONARY FOR FOREIGN STUDENTS
}

\section{OKSANA SAMUSENKO \\ Taras Shevchenko Kyiv National University, Kyiv — Ukraine}

\begin{abstract}
This paper is devoted to the creation of linguocultural image of Ukraine in the process of teaching Ukrainian as a foreign language. The paper deals with the Ukrainian culture-through-language studies. The work focuses on analyzing the cultural component of Ukrainian toponyms, teaching them to foreign students and peculiarities of their interpretation in the Ukrainian culture-through-language dictionary.
\end{abstract}

$\Pi$ роцеси глобалізації привели до значного розширення міжкультурних контактів, що значно вплинуло на розробку нових методичних принципів та параметрів опису іноземних мов та викликало низку реформ у галузі викладання мови як іноземної. Головним принципом новітнього підходу у вивченні європейських мов визначено орієнтацію на оволодіння мовою як засобом спілкування в реальних життєвих ситуаціях, що може стати одним iз чинників розв'язку проблем міжмовної та міжкультурної комунікації, а загалом сприяти діалогу культур. Формування комунікативної компетенції в тих, хто вивчає іноземну мову, відбувається шляхом оволодіння лінгвістичною, соціолінгвістичною, дискурсивною, соціокультурною, соціальною та стратегічною складовими. Під соціокультурною (в іншій термінології - лінгвокраїнознавчою) компетенцією в європейській концепції мовної освіти розуміють знайомство іноземців з національно-культурною специфікою мовленнєвої пове- 
дінки носіїв мови, тобто 3 тими елементами соціокультурного контексту, що $€$ релевантними для породження й сприйняття мовлення з точки зору носіїв цієї мови: звичаї, правила, норми, соціальні умовності, ритуали, країнознавча інформація тощо ${ }^{1}$.

Відповідно до сучасних вимог міжнародної освіти, новітніх підходів до лінгводидактичного опису живих європейських мов та з метою виховання висококваліфікованих фахівців нормативною дисципліною для студентів-іноземців, які навчаються на філологічних факультетах вищих навчальних закладів України, визначено спеціальний курс „Лінгвокраїнознавство української мови”. Цей курс пропонує вивчення мови як відображення національної культури та знайомить студентів з особливостями мовно-концептуальної картини світу українського етносу, розкриває особливості менталітету українців, дає знання з різноманітних галузей життя українського суспільства від давнини до сучасності, допомагає студентам осягнути національно-культурну специфіку лексичної бази української мови, вчить розпізнавати національно-забарвлені смисли в мовних одиницях різних рівнів, закладає основи адекватного перекладу з української мови на рідну мову, сприяє успіхам у комунікації з носіями мови.

Зміна соціальних вимог до сучасного фахівця спричинила зміну в методах і формах освітнього процесу, значимими стали високий рівень самостійності та розвинене продуктивне мислення, і як наслідок - головну увагу у вищій школі стали надавати проблемним методам навчання ${ }^{2}$. Ефективна організація навчального процесу іноземних громадян, що вивчають українську мову, а отже, й лінгвокраїнознавчу дисципліну, включену до навчальних планів підготовки іноземних фахівців - майбутніх філологів-україністів та перекладачів з української мови, потребує забезпечення курсу необхідною навчально-методичною літературою, підручниками та посібниками, лінгвокраїнознавчими словниками та довідниками. Як зауважують викладачі та методисти, „загалом, до цієї роботи можна було б залучити ще чимало спеціалістів і створити багатотомну працю"з. Попри появу в сучасному науковому просторі монографій, лексикографічних праць та значної кількості публікацій з проблем етнолінгвістики, фольклористики, міфопоетики, країнознавства ще чекаємо на фундаментальний посібник з лінгвокраїнознавства та на повний лінгвокраїнознавчий словник з української мови, чим і визначається актуальність пропонованої статті.

Відповідні видання є в різних країнах світу, вони відбивають багату матеріальну та духовну скарбницю певної етнічної спільноти, містять інформацію 3 мови, культури, фольклору, міфології, традицій, звичаїв та є доступними для широкого загалу. Можемо відзначити російський етнолігвістичний словник у п'яти томах Славянские древности та польский словник слов'янських старожитностей у шести томах Słownik starożytności słowiańskichs. Треба сказати, що й в Україні також з'явилися подібні праці. Так, наприклад, словник-довідник В. Жайворонка Знаки украӥнської етнокультури в абетковому порядку містить ,українську лексику, яка в народній мові має етнографічний, етнокультур-

${ }^{1}$ Пороговый уровень: Русский язык, Совет Европы Пресс 1996, т. 1, с. 16.

${ }^{2} \mathrm{O}$. М. С аму сен но, Проблемні методи навчання в лінгвокрайнознавчому курсі украйнської мови для студентів-іноземиів, [в:] „Теорія і практика викладання української мови як іноземної”, Львів 2013, вип. 8, с. 286-297.

${ }^{3}$ Україна в словах: мовокраїнознавчий словник-довідник, Київ 2004, с. 6.

${ }^{4}$ Славянские древности: этнолингвистический словарь, Москва 1995-2012.

${ }_{5}^{5}$ Stownik starożytności stowiańskich: encyklopedyczny zarys kultury słowian od czasów najdawniejszych, Wrocław 1961-1996. 
ний, етноісторичний, етнофілософський, етнопедагогічний, етногеографічний, етнопсихологічний, міфологічний, релігійний та інші національно-забарвлені смислові підтексти"6. Варті уваги ілюстрований мовокраїнознавчий тематичний словник-довідник Україна в словах державного університету імені Лесі Українки, та навчальний посібник викладачів Київського національного університету імені Тараса Шевченка Лінгвокраїнознавство: Україна ${ }^{8}$. В останньому значну частину відведено лінгвокраїнознавчому коментареві, що може бути прототипом словника-довідника, він містить розгорнуту інформацію про основні мовні одиниці української мови, що мають національно-культурну специфіку. Цей розділ посібника має самостійну цінність завдяки тому, що в ньому зібрано тексти, словникові статті, коментарі 3 широкого переліку джерел, міститься систематизована інформація лінгвістичного та енциклопедичного характеру від прадавнього періоду розвитку українського етносу до пострадянських часів. Зрозуміло, що з метою оптимізації навчального процесу та правильного розуміння лексики з національнокультурною семантикою студентам-іноземцям слід пропонувати, крім тлумачних, етимологічних та перекладних словників, лінгвокраїнознавчі словникидовідники, що містили б у стислому вигляді розсіяний в існуючих у сучасному науковому просторі матеріал.

Досвід роботи в іноземній аудиторії, накопичений викладачами та методистами протягом багатьох десятиліть, показує, що особливе значення в процесі вивчення іноземної мови має приділятися не стільки теоретичним основам мови, скільки оволодінню практичною ії складовою - мовленням, а принцип лінгвокраїнознавчої спрямованості повинен ураховуватися вже з перших практичних уроків вивчення іноземної мови, починаючи зі знайомства з лексичним мінімумом та комунікативними формулами на елементарному рівні загального володіння мовою, згодом у процесі оволодіння й удосконалення комунікативних умінь та навичок у ситуаціях соціально-побутового та соціально-культурного спілкування на базовому рівні. На практичних заняттях з іноземної мови на середньому та високому рівнях студенти дізнаються про національно-забарвлені смисли одиниць різних рівнів мови, а на професійному - повинні оволодіти комплексом позамовної інформації з особливостей менталітету, історії, культури, побуту, міфології, етикету тощо українців завдяки спеціальному курсу 3 лінгвокраїнознавства української мови. Як правило, студенти-філологи розуміють спільне та специфічне в поняттях країнознавство, лінгвокраӥнознавство та народознавство. 3 країнознавчою дисципліною знайомляться на підготовчому факультеті, де вивчають історію, географію, економіку, державний устрій, політику, систему освіти та науки, культурне й суспільне життя країни, мову якої вивчають. Народознавство, чи етнографію, розуміють як галузь історичної науки, що вивчає культуру й побут народів світу, їхнє походження, особливості розвитку матеріальної та духовної культури. Лінгвокраїнознавство як розділ мовознавства, опановують пізніше: вивчають мову з огляду на ії культуроносійні функції та знайомляться з типовими явищами національної дійсності через посередництво мови і в процесі іiї вивчення. Для майбутніх філологів та перекладачів значущими $\epsilon$ міра й ступінь оволодіння національно-культурними та асоціативно-образними компонентами семантики слова (експресивними, емо-

${ }^{6}$ В . В. Жа й в ор о н ок, Знаки украӥнської етнокультури: словник-довідник, Київ 2006, с. 4.

7 Україна в словах: мовокраїнознавчий словник-довідник, Київ 2004.

${ }^{8}$ О.М.С амусенко, О.І.Клімкін а, Лінгвокраїнознавство: Украӥна, Навч. посібник, Київ 2009. 
ційними, оцінними, часовими, територіальними, функціональними тощо), що часто є головними й розкривають основне лексичне значення цього слова. Зважаючи на все сказане, в методиці викладання іноземних мов має бути визначено лінгвокраїнознавчий потенціал лексичного ядра української мови, критерії відбору та презентації в навчальному процесі мовних одиниць 3 національно-культурною семантикою, способи репрезентації безеквівалентної та фонової лексики.

Особливу увагу в наведеному контексті фахівці приділяють топонімам. Російські методисти зокрема відзначають, що в топонімах російської мови відображено історію заселення та освоєння територій сучасної Російської Федерації, й хоча деякі географічні назви відомі й за межами Росії та мають стійкі відповідники в мовах усього світу, однак у носіїв інших культур можуть не виникати пов'язані з цими об'єктами асоціації, що є невід'ємною частиною російської історії ${ }^{9}$. До переліку основних країнознавчих відомостей про Росію вже на середньому (В1) рівні входять найменування частин світу, де розташована країна, географічні регіони, назви річок, озер, гір, морів, назви міст та суб' єктів РФ, тобто назви республік, областей, районів, автономій тощо ${ }^{10}$.

У мовокраїнознавчому довіднику Україна в словах, як зауважують у передмові укладачі, кількість культурологічних слів обмежена, а власні географічні назви не увійшли до словника взагалі. Однак у розділі „Наша держава — Україна" розміщено слова на позначення історико-етнографічних районів у сучасному вигляді (Бойківщчина, Буковина, Волинь, Гуцульщзина, Закарпаття, Опілля, Південь, Поділля, Покуття, Полісся, Прикарпаття, Слобожанщина), також назви основних етнічних регіонів, що частково або повністю містяться за межами кордонів української держави (Берестейщина, Бессарабія, Лемківщиина, Надсяння, Перемищина, Підляшшя, Холмщина), а також окремо подані Крим та Таврія. Реєстр словника Знаки української етнокультури вміщує окремі географічні найменування, з якими тісно переплетені історична доля та світогляд українського народу, багато з них стали знаками національної культури: Батурин, Борисфен, Буковина, Галичина, Гетьманщчина, Гуиульщина, Дніпро, Дністер, Срусалим, Закарпаття, Карпати, Киї, Київська Русь, Коломия, Крим, Лівобережжя, Московщина, Підкарпатська Русь, Покуття, Полісся, Правобережжя, Прикарпаття, Слобожанщина, Суботів, Україна, Цареград. Як бачимо, ці словники висвітлюють лише частково топонімічні одиниці української мови, але обов'язково включають назви історико-етнографічних регіонів — „етнотериторіальних утворень в межах усього етносу, які за історичною долею та етнічними особливостями є самобутніми, зафіксованими в історичних документах і відтвореними у крайовій символіці та історичній пам'яті людей”"11. До переліку цих одиниць додатково можуть увійти як давні назви (напр., Роксоланія, Рустія, Галицька земля, Холмщина, Червона Русь, Подолля, Сівера), так і назви сучасного поділу України на три історико-етнографічні регіони: ЦентральноСхідний (або Південно-Східний), Північний та Західний (Південно-Західний), що мають свої райони та підрайони (Бойківщчина, Буковина, Волинь, Галичина, Гуцульщчина, Закарпаття, Лемківщчна, Опілля, Поділля, Покуття, Полісся, Прикарпаття, Слобожанщзина, Наддніпрянщина). Оскільки топоніми часто характеризують місцевість з точки зору тих народів, які населяють чи населяли iii раніше, крім наведених найменувань, на заняттях в іноземній аудиторії варто

${ }^{9}$ Н. Л. Фе до тов а, Методика преподавания русского языка как иностранного (практический курс), Санкт-Петербург. 2013, с. 140.

${ }^{10}$ Пороговый уровень: Русский язык, Совет Европы Пресс 1996, т. 1, с. 146-148.

${ }^{11}$ Українська етнологія, Київ 2007, с. 44. 
звернутися також до назв етнографічних груп українців (литвини, полішуки, волиняни, галичани, гуцули, лемки, бойки, буковинці, волиняни, тутейші), які етимологічно виводяться з назв історико-етнографічних регіонів України.

Наведемо спробу висвітлення поняття Гуцульщина в лінгвокраїнознавчому словнику-довіднику. Гуцульщина - історико-етнографічний регіон, що розташований у Карпатах та на їхніх схилах у межах Закарпатської, Чернівецької та Івано-Франківської областей, а також на території Румунії; це край українських верховинців. Гуиули (гуцул, гуцулка) - субетнос українців, які живуть на цих територіях (Верховинський район, південна частина Косівського й Надвірнянського районів Івано-Франківської області, Путильський та південна частина Вижницького району Чернівецької області, більша частина Рахівського району Закарпатської області). Існують різні теорії походження слова. За одними з них лексема гуиул походить від молдавського чи румунського гои, гуц, готель „розбійник, опришок”, за іншими - від слова кочувати, кочули „пастухи”, назву пов'язують з дієсловом гощзати, гуц̧ати, тобто підстрибувати, підскакувати в танці. Перші історичні відомості про Гуцульщину з'явилися в польських джерелах XIV-XV ст. У різні часи Гуцульщина входила до складу Туреччини, Молдавії, Польщі, Угорщини, Австрії, Румунії, Чехословаччини. Тепер уся Гуцульщина, за винятком декількох сіл, розміщена на території України. Гуцули живуть у горах, мають самобутні хати, зберігають національні традиції, народні вірування, звичаї, розмовляють на діалекті - гуцульським (східнокарпатським) говором. Гуцули займаються вівчарством, мають розвинене килимарство, ткацтво, гончарство, різьбярство. У всьому світі відомі гуцульські вишивки, килими, писанки, глиняний посуд, вироби з дерева.

Знайомство 3 поданим матеріалом закладає основи створення у свідомості іноземців образу цього багатого краю та його мешканців, але не дає змоги осягнути самобутність, оскільки для іноземців залишаються невідомими етнокультурні підтексти, що є звичними й зрозумілими без пояснень для українців. Невеликий вільний асоціативний експеримент, що було проведено серед молодих українців (25-35 років), які мають вищу освіту та проживають у Києві, дозволив встановити певний асоціативний ряд на слова-стимули Гуцульщзна та гуиул, які подаємо за частотністю (від часто згадуваного до одиничного). Респондентами було названо такі перші слова, що виникли як асоціації на запропоновані слова-стимули: на лексему Гуцульщчина: Західна Україна, гори, Карпати, ліс, смерековий ліс, таниі, танцюристи, традииійна українська культура, всі у вишиванках, гарні краєвиди, збереження звичаїв та обрядів, діалект, бануш, Тіні забутих предків, легенди; щодо лексеми гуиул маємо таку низку асоціацій: трембіта, парубок у національному костюмі з трембітою, співак, танцุюрист, українська мова, бравий та запальний парубок, жупан, отари овець, гарна гуиулка, жадібний. Зрозуміло, що ці асоціації не виникають у іноземців, які вивчають українську мову, а отже, завдання викладача - різними засобами змалювати цей образ. Долучитися до етнокультури допоможуть наочні матеріали, література, художні та документальні фільми, сучасні та фольклорні пісні, музика - все, чим багатий цей край. Гуцули зображені у фільмі Юрія Іллєнка Білий птах з чорною ознакою та у фільмі Сергія Параджанова Тіні забутих предків. Популярна пісня Гуиулка Ксеня, гуцульські коломийки, прислів'я, приказки, загадки, певні особливості гуцульської говірки додадуть довершеності образу цього краю. 
Укладаючи топонімічну словникову статтю, слід згадати про невідомі конотації історико-соціального плану в назвах загальновідомих українських міст, містечок, сіл, місцевостей (Батурин, Бориспіль, Великі Сорочинці, ВолодимирВолинський, Запорозька Січ, Петриківка, Харків, Чигирин, Чорнобиль) ${ }^{12}$; вказати на першоджерела топонімів - назв відомих українських міст (Київ, Львів, Корсунь-Шевченківський, Переяслав-Хмельницький, Хмельницьькии,, ІваноФранківськ); навести символічні та метафоричні значення онімів, що пов'язані 3 певними подіями української історії (Запорозька Січ — ,демократичний устрій суспільства”, „незалежність”, „вольниця”; Гуляйполе — „зона анархії, безлад”; Жмеринка — „провінційне містечко, глушина”; Чорнобиль — образсимвол глибокої кризи) $)^{13}$; з'ясувати імена міфологічних персонажів, які залишилися в сучасних географічних назвах: Волосів Яр (на Вінниччині), Волоська вулиия (у Києві); городище Саварка або Свароме (на Київині), село Сваричів (на Івано-Франківщчині); Перунова рінь (на Дніпрі), село Перунове, урочшще Перуни (на Черкашині); поселення Макошине (на Чернігівщзині); окреслити причини перейменувань відомих українських міст: Катеринослав $\rightarrow$ Новоросійськ $\rightarrow$ Січеслав $\rightarrow$ Дніпропетровськ; Юзівка $\rightarrow$ Сталіно $\rightarrow$ Донеиьк; Олександрівка $\rightarrow$ Запоріжжя; Юр'єв $\rightarrow$ Біла Церква; Хаджибей $\rightarrow$ Одеса тощо.

Отже, зазначимо, що в словниковій статті лінгвокраїнознавчого словникадовідника, зокрема такій, що репрезентує топонімічні назви, повинні бути вміщені такі відомості: назва, варіанти назви; дефініція; екстралінгвістичний матеріал; граматичні особливості лексеми, що є необхідними для іноземців (рід, форма множини, родовий відмінок множини тощо); етимологічна характеристика та словотвірні особливості; синонімічні ряди чи антонімічні пари (якщо можливі); епітети; національно-культурні компоненти семантики, історикокультурні конотації; усталені вислови, прислів'я, приказки; фіксація в художній літературі, фольклорі, наукових виданнях; посилання на художні та документальні фільми, інший ілюстративний матеріал; джерела основної та додаткової інформації.

Підсумовуючи, наголосимо, що поява в останні десятиліття великої кількості мовно-культурно-етнографічних розвідок, що, як правило, розраховані на фахівців або широке коло читачів, які цікавляться глибинами українського слова, може стати підгрунтям для лексикографічних та лінгводидактичних праць, а накопичений матеріал у перспективі дасть змогу створити багатотомний лінгвокраїнознавчий словник-довідник для тих, хто прагне вивчати українську мову як іноземну.

${ }_{12}^{12}$ М. П. Янко, Топонімічний словник Украйни: словник-довідник, Київ 1998, с. 72.

${ }^{13}$ Е. С. О ти н, Словарь коннотативных собственных имен, Донецк 2004, с. 121-142. 